\title{
Correction: Interleukin 21 Signaling in B Cells Is Required for Efficient Establishment of Murine Gammaherpesvirus Latency
}

\section{The PLOS Pathogens Staff}

There is an error in Table 1, which was introduced during the typesetting process. The publisher apologizes for this error. The data given for day 20, Total YFP+ PCs (SEM) in the IL21R-/mice reads: “3)”. It should read: “448 (83)". Please see the corrected table here.

\section{fopenaccess}

Citation: The PLOS Pathogens Staff (2015) Correction: Interleukin 21 Signaling in B Cells is Required for Efficient Establishment of Murine Gammaherpesvirus Latency. PLoS Pathog 11(5): e1004922. doi:10.1371/journal.ppat.1004922

Published: May 13, 2015

Copyright: @ 2015 The PLOS Pathogens Staff. This is an open access article distributed under the terms of the Creative Commons Attribution License, which permits unrestricted use, distribution, and reproduction in any medium, provided the original author and source are credited. 
Table 1. Average number of $\mathrm{YFP}^{+}$cells per spleen.

\begin{tabular}{|c|c|c|c|c|c|c|}
\hline & \multicolumn{2}{|c|}{ Total YFP+ cells (SEM) ${ }^{\mathrm{a}}$} & \multicolumn{2}{|c|}{ Total YFP+ GC B cells (SEM) ${ }^{b}$} & \multicolumn{2}{|c|}{ Total YFP+ PCs (SEM) ${ }^{c}$} \\
\hline & C57BI6 & $\| 21 R^{-/-}$ & C57BI6 & $\| 121 R^{-/-}$ & C57BI6 & $\| 21 R^{-/-}$ \\
\hline d14 & $21,129(6,898)$ & $6,012(1,256)$ & $14,360(4998)$ & $2,515(644)$ & $4,034(1,398)$ & $1,127(264)$ \\
\hline d16 & $313,528(117,143)$ & $17,966(3,414)$ & $273,788(110,482)$ & $9,772(1,929)$ & $37,081(13,599)$ & $1,823(327)$ \\
\hline d18 & $254,735(72,400)$ & $20,579(5,316)$ & $200,146(56,323)$ & $14,089(4170)$ & $29,466(7,862)$ & $1,088(248)$ \\
\hline d20 & $84,718(25,889)$ & $9,637(2,317)$ & $65,518(20,896)$ & $4,648(1,019)$ & $7,641(2,145)$ & $448(83)$ \\
\hline
\end{tabular}

a. Calculated from mice infected in Fig $1 \mathrm{~A}$ and $1 \mathrm{~B}$.

b. Calculated from mice infected in Fig $5 \mathrm{~A}$ and $5 \mathrm{~B}$.

c. Calculated from mice infected in Fig 2C and 2D.

doi:10.1371/journal.ppat.1004922.t001

\section{Reference}

1. Collins CM, Speck SH (2015) Interleukin 21 Signaling in B Cells Is Required for Efficient Establishment of Murine Gammaherpesvirus Latency. PLoS Pathog 11(4): e1004831. doi: 10.1371/journal.ppat. 1004831 PMID: 25875847 